\section{Coping with cuts}

SIR - The sad plight of UK universities facing increasing costs and diminishing financial support, possibly even the elimination or demotion of "redundant" universities, moves me to suggest an arrangement not uncommon in American universities, whereby members of university faculties have 9-month rather than 12-month appointments.

This means that faculty members have 3 months in the year free for other activities. Scientists and engineers can frequently find summer employment in government and industrial laboratories, where the broader experience may well be beneficial to their university teaching and research. In any case, the experience may be valuable in combating the ivory tower outlook and maintaining contact with the real world. Colleagues in the humanities may find it more difficult to obtain alternative summer employment, but they would be free to write books, paint pictures, compose music and thereby practice the arts they teach.

In many cases, it may not be necessary for the "9-month scientist" to forsake his laboratory. A large part of American (meaning US) university research is funded by grants from government agencies and from industries. It is common practice for a reseurch proposal to include not only support for a post-doc associate or a graduate student assistant, but also an item for 50 per cent or even 100 per cent of the time of a faculty member for two or three months of the year. Such support is by no means automatic but depends on the quality of the proposal, that is, on the quality of the person making the proposal.

Thus in one way or another the really capable people on university staffs can add usefully to their salaries and those who have "retired" from active productive scholarly work and have little or no standing in their subjects are left where they belong, at a lower level on the financial ladder.

Much good can come from the operation of the free enterprise system, and those who prefer the old, easy-going ways must accept lower annual remunerations.

\section{Pennsylvania State University,} G.W. BRINDLEY Pennsylvania, USA

\section{Nuclear electricity}

SIR - In commenting on the analysis of relative costs of nuclear and coal-fired electricity given in Appendix 3 of the Central Electricity Generating Board (CEGB) 1979/80 Annual Report, I stated that "the full calculation (of costs corrected for inflation) can only be undertaken when the CEGB decides that its present policy of withholding the data . . . is counterproductive" (Nature 287, 674; 23 October 1980). I had first asked in specific detail for the data at the beginning of September 1980 and had pursued the matter through both the Department of Energy and the CEGB to the extent of getting a discussion meeting with both department and board officials present. In spite of this the detailed figures of capital cost only became available at the end of March 1981 and then only as the result of a parliamentary question put down on 2 February.
The results of the present calculations, utilizing the newly available data are summarized in the table below. These calculations are significantly different in method from those used in an earlier paper (Energy Policy, December 1980, p.344-6) and referred to in my letter of 23 October. The retail price index (RPI) has been used to correct for inflation and a uniform interest rate of 5 per cent has been applied instead of the historic National Loans Fund rate.

However, as the table below shows, even with these modifications the inflation corrected cost of nuclear electricity from Magnox stations is still 18 per cent above that of comparable coal fired stations, instead of 17 per cent below as given by historic costs, and if a previously unconsidered effect of inflation on nuclear fuel costs is included, the margin becomes 34 per cent above that for coal.

Calculations similar to those for the stations of Table 1, Appendix 3 have been done for Hinkley Point B and Drax (first half) (Table 2). The results are also given below. The full paper giving the details of the calculations and dealing also with stations under construction and future stations (Tables $3 \& 4$, Appendix 3) is in preparation (to be submitted to Energy Policy).

\section{Generation costs at nuclear and conventional stations (pence per $\mathbf{k W h}$ 1979/80 prices) \\ Stations commissioned between 1965 and 1979

$\begin{array}{lrrr} & 1 & 2 & 3 \\ \text { Nuclear } & 1.30 & 2.06 & 2.34 \\ \text { Coal-fired } & 1.56 & 1.75 & 1.75 \\ \text { Nuclear/Coal \% } & 83 & 118 & 134\end{array}$

Hinkley Pt $B(A G R)$ and Drax (first half) (coal-fired)

Hinkley Pt B

(nuclear)

Drax (first half)

(coal-fired)

$\begin{array}{cccc}4 & 5 & 6 & 7 \\ 1.35 & 1.80 & 2.06 & 2.38\end{array}$

Nuclear/Coal \%

$\begin{array}{llll}1.52 & 1.69 & 1.69 & 1.69\end{array}$

Notes to columns: (1) Historic costs as given by CEGB in

Table 1, Appendix 3, 1979/80 Annual Report. (2) RPI

corrected capital costs, 5 per cent interest rate and fixed costs corrected for load factor equal to availability. (3) As 2, but with the addition of an estimated minimum inflation

correction for nuclear fuel costs. (4) Historic costs as given by CEGB in Table 2, Appendix 3, 1979/80 Annual Report. (5) RPI corrected capital costs and 5 per cent interest rate. (6) As RPI corrected capital costs and 5 per cent interest rate. (6) A
5 , but with the addition of an estimated minimum inflation correction for nuclear fuel costs. (7) As 6, but estimated probable fuel cost correction.

Finally may I take up one point in Dr Jones's letter (Nature 288, 638; 1980) in which he criticizes my use of the combined coal and oil fuel costs in Fig. 1 of my letter of 23 October. Separate coal fuel costs in $\mathrm{p} / \mathrm{kWh}$ similar to the combined ones of Table 9 of the CEGB Statistical Yearbook are not available, but figures of coal prices to the CEGB in $p / G J$ from 1960/61 to 1979/80 have been supplied by the Commercial Controller. When the real price index is normalized to equality with the coal and oil figures for 1972/73 and plotted on the same graph there is no significant difference between the points. I understand from $\mathrm{Dr}$ Jones that he was considering National Coal Board production cost data which may well give a different picture, but it is the price to CEGB and specifically the coal fuel cost in $\mathrm{p} / \mathrm{kWh}$ which I was dealing with and my graph is an accurate reflection of this.

Birkbeck College, J.W. JEFFERY

Malet Street, London WCl, UK

\section{Attack on Tamuz}

SIR - Your recent editorial "Making Israel atone for Tamuz" (Nature 18 June, p.523) leaves out many facts which are important in considering the reasons for Israel's attack and the reality of the situation.

As you and I are aware, nations do what is in their best interest regardless of what treaties they do or do not sign. Just because one nation is a signatory of the Non-Proliferation Treaty does not mean that it will not produce a nuclear weapon. Iraq has been one of Israel's most aggressive and belligerent neighbours, and in fact these two countries are still at war with one another, as no peace treaty has ever been signed. What could this or any other country do if indeed Iraq or any other nation had a nuclear weapon and threatened to use it against an enemy? We could not stop the Soviet Union from invading Afghanistan, nor prevent the problems of Iran. We cannot even clear up the fighting in Lebanon. The world needs Iraq's oil, so "international pressure" would never work.

I agree with your statement concerning the use of oil to generate hydroelectric power, but why did Iraq refuse to accept lower grade uranium that would work very well in a nuclear reactor to produce electricity, but would not be able to produce atomic weapons? Iraq demanded from France weapons grade uranium or their oil supply treaty would be null and void. In addition, one of the inspectors from the International Atomic Energy Agency stated during an interview that the reactor at Tamuz could easily have produced nuclear weapons and that such production could have been shielded from any inspector, thus making the whole question of on-site inspection ludicrous. Although Iraq was supposed to return the spent uranium to France for reprocessing, Iraq also had uranium already purchased from Third World nations, thereby bypassing France completely. You also do not mention that Iraq had contracted with Italy to build a "hot cell" plant that would also allow for enriching and processing plutonium for no other purpose than to build an atomic bomb.

M.S. PASCAL

Englewood, New Jersey, USA

SIR - Israel's attack on the Iraqi reactor may have been politically unwise, even immoral (although I suspect Benthamites might be able to generate some fairly strong Utilitarian arguments in support of the raid). It is, however, something approaching hyperbole to characterize the raid as a flagrant violation of international law (Nature 18 June, p.523), as Iraq remains in a technical state of war with Israel, and has repeatedly called for the destruction of the "Zionist entity".

It is also somewhat naive, to be gentle, to assert that Iraq's acceptance of the principles of the Non-Proliferation Treaty assures compliance with its provisions. Soviet citizens who seek the enforcement of the principles of the Helsinki accord often must pack for very cold climates on very short notice.

On judgement day when we must all atone, there may be many whose need for absolution will be greater than that of the Israelis.

New York, USA 